\title{
Sciendo
}

\section{Inequalities and Conflicts in Modern and Contemporary African History: A Comparative Perspective}

\author{
STEPHANO LAZARO AYO \\ Department of Ethnology and World Studies, \\ University of Ss. Cyril and Methodius in Trnava, Slovakia \\ ayo2@ucm.sk
}

Department of History, Political Science and Development Studies, Dar Es Salaam University College of Education, Tanzania

For decades, most of Sub-Sahara African countries have been marred with violent conflicts and political unrest. Scholars and analysts have pointed colonial legacy, creation and instrumentalisation of ethnic identities (MAMDANI 2001:1-28; WANJALA S. 2015:xi-xii, 1-4), corruption, greed and grievances (HOEFFLER 2011:274-284), manifestation of systemic inequality and marginalization (FUKUDA-PARR - ARNIM - MINE 2013:1-9), religious stereotypes (JOHNSON 2003; WILLIAMS 2011), as well as governance and economic policies (ASCHER - MIROWITSKAYA, Natalia 2013; MINE - STEWART FUKUDA-PARR - MKANDAWIRE 2013) as the root causes of wars and conflict in Africa. However, none of the above mentioned factors solely explains the degree and variation of violence in the continent. Ascher and Mirovitskaya, and Johnson admit that armed conflicts in Africa should not be understood in generic terms like ethnicity or through Collier and Hoeffler's dichotomies of "greed and grievances" (ASCHER - MIROWITSKAYA 2013:2; JOHNSON 2003:xvi-xviii). Instead, multiple circumstances and the related catalysts should properly be studied so as to understand the causes of wars and violent conflicts in Africa. 
In the view of the above, Jan Záhořík in Inequalities and Conflicts in Modern and Contemporary African History, offers a comparative historical account on the multiple circumstances, causes, and consequences of conflicts, wars, and political unrest in Africa. He approaches the subject to unveil the subterranean forces which have, since the $20^{\text {th }}$ century, contributed to growing violent conflicts in the continent. Záhořík uses interdisciplinary approach by engaging historical, ethnological, political, international and other dimensions in order to enlighten the multiple facets which shape the contemporary conflicts and wars. The author points out that conflicts in Africa should be examined on the basis of "broader global trends and as a result of interaction between local and global forces" (viii). One of the strengths of this book is its accessibility in terms of language use, thematic and structural organization. The book is organized into three chapters. His arguments enable a reader to weave through multiple circumstances rooted in historical, socio-economic and political dimension such as ethnicity, separatist politics, ethno-nationalism, marginalization and inequality (vii-x).

The author's motive for studying "conflicts in Africa into broader perspective that simply goes beyond colonial legacy" (vii), is to dispute the popular narrative which use colonialism as a sole factor for conflict in Africa. However, this argument appears to belittle colonialism and colonial legacy. He uses the absence of physical colonial domination in Ethiopia and Liberia to dispute colonial legacy. He argues that Ethiopia did not experience serious foreign colonial domination for a long period time, and thus, colonialism and colonial legacy cannot fit in accounting for its prolonged political tension, conflicts and wars (vii, pp. 6-7, 41, 85) This however, is an attempt to undermine colonialism, colonial legacy, neo-colonial relations, and imperial agenda of the postmodern era. The author considers colonialism in physical or regional terms and not as holistic phenomenon which also involved spread of ideas, attitudes, psychological and social dimensions.

In this book, the author articulates the historical roots that have resulted in current political turmoil in different regions in Africa. He digs deeper into colonial times in order to establish relationships between past and present. To him, this is the only reason that justifies "why does history matter" (ix). In the course of articulating how colonial policies and strategies are linked to the present, a detailed comparative historical analysis is provided demonstrating how colonial strategies and policies inculcated ethnicity, regional, economic, and social marginalization, superiority complex, and undemocratic attitude. The historiographical discussion offered and the capture of bipolar politics of the Cold War time acts as the basis for the realization of the central thesis of the book. However, the author approaches the Ethiopian question idealistically by ignoring the context of time and spread of colonial ideas of the late $19^{\text {th }}$ century. The fact that colonial ideas of racism, superiority, conquest, and 
domination were real, Ethiopia could not operate in isolation for it to survive. It was these similar ideas of the ruling dynasty which implanted the seed to current tensions and unrest in Ethiopia and the Horn of Africa at large.

A comparative discussion on multiple sources of conflicts, war, and political unrest in Africa is provided by examining countries with prolonged conflicts, wars or those with critical and devastating impacts of instability such as Rwanda, Burundi, Congo, and Nigeria. Záhořík insists that "conflicts and various political turbulences usually have more than one root cause or variable" (p. 43). His historical comparative approach in studying different cases reveals failure of de-colonisation, separatist politics, ethno and regional nationalism, socioeconomic, political marginalization, and inequalities as contributing factors for conflicts and wars. The author criticizes the tendency of putting economic motives in explaining conflicts in Africa and calls for an "inter-disciplinary approach combining historical and anthropological inquires to political science and political economy” (p. 68). By this, Záhořík criticizes economic determinism in explaining conflicts in Africa. This argument, however, lightly considers the fact that economic base, and mode economic exploitation set the motion for cultural, social, and political relations which develops in a given society (AMIN 2014:110, 55-79; BADRU 1998). The motives behind separatist politics, socio-economic marginalization, and inequalities or even the recent South African xenophobic chaos cannot be easily accounted without a critical examination of the actors of the neo-colonial and neoliberal economies operating throughout the continent in a postmodern flavour.

In a detailed discussion, Záhořík examines the extent to which marginalization, inequalities, ethnicity and race, ethno-nationalism, regional and religious conflicts, and many other circumstances have been contributing to conflicts, wars, and political unrest in Ethiopia, and the Horn of Africa. He qualifies the central thesis of the book and the repeated argument that conflicts in Africa are a product of multiple causes, and can never be entirely attributed to its colonial legacy. The author uses historical approach to analyze and examine the evolution of the Amharic dynastic imperial expansion to different regions of what is now modern Ethiopia. He approached this question by examining the Semitic speaking people, the Amharic (the center), expansion to the regions of Cushitic communities, Oromo, Somali, and Afar (the Periphery), and many others, mainly the Omotic, and Nilo-Saharan ethnic groups. Ethnic and racial stereotype, religious favoritism, discrimination and subjugation, regional marginalization and inequalities, political alienation as well as the division of people into classes of citizens and subjects, are used by the author to provide an account that European invasion and domination is not the only source of political conflicts and wars in Africa. 
Záhořík has successfully demonstrated ways in which complexities of inter-racial, ethnic, religious, and regional tension which shape the state of contemporary Ethiopia and other parts of Africa. He does so, just like Pade Badru (BADRU 1998) by criticizing the use of ethnicity as a scapegoat of explaining tension in Ethiopia and other parts of Africa. Despite his ability to exploit contemporary sources (social media, internet and communication technologies) to examine contemporary politics and tension in Africa, there is relatively less attention on archival and oral sources thereby making the book devoid of people's voices in accounting for conflicts in Africa. Cases of Rwanda, Burundi, and Congo for example, require an ethnographic study and thorough review of local and international reports to be in a position to account for the prevailing circumstances in those regions.

To those who intend to study the nature and complexity of contemporary African conflicts, wars and political unrest, this book presents itself as both a critic to the meta-narratives like nationalist narratives and ethnic activists on the one hand. On the other hand, it provides an analytical examination of the complex circumstances from which the contemporary Africa confronts. The author might have been inspired by the contemporary crisis in the Horn of Africa, particularly Ethiopia and his earliest research as a historian of modern and contemporary history and politics in Africa.

\section{Bibliography}

AMIN, Samir (2014): Capitalism in the Age of Globalization the Management of Contemporary Society. London \& New York: Zed Books.

ASCHER, William - MIROWITSKAYA, Natalia (eds.) (2013): The Economic Roots of Conflict and Cooperation in Africa. New York: Palgrave McMillan Publisher.

BADRU, Pade (1998): Imperialism and Ethnic Politics in Nigeria, 1960-1996. Asmara: Africa World Press.

COLLIER, Paul - HOEFFLER, Anke (2004): Greed and Grievance in Civil War. In Oxford Economic Papers Vol. 56, No. 4, pp. 563-595.

FUKUDA-PARR, Sakiko - ARNIM, Langer - MINE Yoichi (2013): Introduction: Disentangling the Linkages between Horizontal Inequalities and Political Institutions. In Yoichi Mines, Frances Stewart, Sakiko Fukuda-Parr, Thandike Mkandawire (eds.): Preventing Violent Conflict in Africa: Inequalities, Perceptions and Institutions. Hampshire: Palgrave McMillan Publisher, pp. 1-9. 
HOEFFLER, Anke (2011): 'Greed' versus 'Grievance': A Useful Conceptual Distinction in the Study of Civil War? In Studies in Ethnicity and Nationalism Vol. 11, No. 2, pp. 274284.

JOHNSON, Douglas H. (2003): The Root Causes of Sudan Civil Wars. Oxford: James Currey.

MAMDANI, Mahmood (2001): When Victims Become Killers: Colonialism, Nativism, and the Genocide in Rwanda. New Jersey: Princeton University Press.

MINE, Yoichi - STEWART, Frances - FUKUDA-PARR, Sakiko - MKANDAWIRE, Thandike (eds.) (2013): Preventing Violent Conflict in Africa: Inequalities, Perceptions and Institutions. Hampshire: Palgrave McMillan Publisher.

WANJALA S., Nasong'o (2015): The Roots of Ethnic Conflict in Africa. Hampshire: Palgrave McMillan Publisher.

WILLIAMS, Paul D. (2011): War and Conflict in Africa. Malden: Polity.

\section{Reviewed Book}

ZÁHOŘÍK, Ján (2019): Inequalities and Conflicts in Modern and Contemporary African History: A Comparative Perspective. London: The Rowman and Littlefield Publishing Group 2019. 